\title{
The Analysis of School Children's Food Consumption (10-12 Years) Using Optifood Application in the City of Medan
}

\author{
Ernawati Nasution ${ }^{1}$, Albiner Siagian ${ }^{2}$, Etti Sudaryati ${ }^{3}$, and Fikarwin Zuska ${ }^{4}$ \\ \{nasutionernawati38@yahoo.com ${ }^{*}$, albiner_sgn@yahoo.com ${ }^{2}$, sudaryatiety@yahoo.com ${ }^{3}$, \\ fikarwin@usu.ac.id $\left.{ }^{4}\right\}$ \\ Faculty of Public Health, Universitas Sumatera Utara, Medan, Indonesia ${ }^{1234}$
}

\begin{abstract}
Food consumption of school children is one of the determinants of nutritional status and learning achievement. Optifood is an application developed by WHO that can describe nutritional intake and produce food formulas that can be used as a guide for a healthy diet, especially during this COVID-19 pandemic. This descriptive study used a cross sectional design. Data was collected by interview using a 24-hour food recall form and food frequency. Data were analyzed using optifood application. The results showed that school children consumed food from the Grains group and grain products (rice and noodles) 7 times a week. The meat, fish and egg group (burgers, fried chicken and eggs) and the savory drinks and snacks group (sweet tea, soft drinks, chatime, chiki, and chitato) $4 \mathrm{x}$ a week. School children very rarely eat vegetables and fruit. Consumption of foods that are high in calories and low in fiber in school children can cause problems of overweight and the risk of obesity.
\end{abstract}

Keywords: Food consumption, School children, Optifood

\section{Introduction}

The current Covid-19 pandemic has forced several countries to take precautions to save their citizens by implementing a lockdown. Indonesia is one of the countries that has also prevented the spread of COVID-19 by implementing a lockdown in several areas of the country, stopping all social activities by closing schools, companies, entertainment venues, markets, parks, and other social gathering places. The government's activities to close schools require children to carry out the teaching and learning process at home. This condition makes children stay at home more, consume more food and lack of physical activity. Lifestyle and eating pattern like this for a long time can put children at risk overweight and even obesity.

Obesity in children is one of the nutritional problems besides stunting which is currently a concern. The obesity rate in Indonesia is currently quite high. Based on the 2018 Riskesdas data, it shows a figure 21.8 percent for obesity in Indonesia. This figure has continued to increase since Riskesdas 2007 by 10.5 percent and 14.8 percent in Riskesdas 2013[1].

The cause of this obesity problem is the consumption of unbalanced nutrition and low physical activity. So, to overcome this problem, one way is to know the child's eating pattern and improve their eating pattern. School children are a group that must receive attention in terms of food consumption. For school children, food serves to maintain the process of growth and development as well as replace damaged body tissue, obtain energy to carry out daily activities, 
and defend the body against various diseases. In addition, adequate food consumption is also related to children's learning abilities while at school which can support their learning achievement. In order for food to function as described previously, the food we consume daily is not just food, but also contains certain nutrients so that it fulfills this function.

Research conducted by Badriyah and Gamal [2], found that there is a relationship between food consumption and nutritional status with student achievement. This shows the importance of food consumption for students which is manifested in their nutritional status. Because to achieve optimal student learning achievement, good and quality food intake is needed.

One way to find out what is consumed by children can use the optifood application. Optifood is a linear programming software that uses mathematical optimization to calculate how to improve and increase diets at the lowest cost using locally available foods. Optifood identifies gaps in current diets, and suggests locally available foods to fill those gaps. Optifood also show the limits of locally available foods in providing essential nutrients. There have been many studies using this optifood application.

However, to respond to this challenge, scientists have developed an approach based on linear programming into a "user-friendly" tool, meaning that it is easier to use, WHO in collaboration with the London School of Hygiene and Tropical Medicine (LHSTM), Food and Nutrition Technical Assistance II Project (FANTA-2) and an information technology company, developed optifood which is a software program designed to facilitate data entry, presentation of output, and management of input and output data storage for modeling food and nutritional intake [3]. Optifood has been used in several countries to assist in overcoming nutritional problems such as in Guatemala, Kenya, Kamboja, Vietnam, including Indonesia.

Actually, there are other applications that can describe the food consumption of a person or group, namely the Nutri Survey, but this application cannot describe the maximum each type of food consumed by a person or group. The optifood application can describe the consumption picture in addition to the average per week also the maximum consumed per week. So based on the description above, the problem in this study is how the description of school children's food consumption (type and frequency) is based on an analysis using the optifood application.

\section{Methodology}

This descriptive study used a cross sectional design on 156 elementary school children taken from 6 elementary schools in Medan City which were taken by purposive random sampling, namely school children in fourth and fifth grades on the grounds that these children were cooperative in data collection. Food consumption data was collected by means of interviews using food recall and food frequency forms. This eating consumption analysis uses the optifood application. The optifood application analysis process is carried out through three stages called modules, namely module I (check diets), module II (identify draft recommendations), and module III (test draft food-based recommendations).

The division of these three stages because each of these modules will carry out a different analysis process [4]. Module I is executed after the entry list of food compositions (obtained from food recall). Module I was carried out to determine whether possible solution could be generated from the data on food intake and eating patterns of the target group. Module I also specifically examine size limits of food types, food groups, and food subgroups, to ensure that sufficient food choices are obtained to form a diet model and ensure that some individuals from the target group can consume them. Module II was carried out to identify the best food sources 
and food groups of micronutrients in the available diet that can be increase to address the nutritional problem "problem nutrient" in Module III. This test begins by conducting an analysis without adding any food before testing the FBR design. This is done to provide a basic diet that will be compared with different alternative FBRs. This basic diet can be used to compare nutrient levels when testing each FBR to assess whether the percentage RNI of each nutrient being discussed in the worst scenario is significantly increased compared to existing practice. In this study, we look at the consumption picture from the results of optifood analysis in Module I, namely the results of diet analysis.

\section{Result and Discussion}

\subsection{Result}

The students in this study were mostly male as many as 67.3 people $(67.3 \%)$ and most of the students had pocket money around Rp. 1000 to Rp. 10,000, - as many as 94 people $(60.3 \%)$. More clearly can be seen in the following table.

Table 1. Student Frequency Distribution Based on Characteristics

\begin{tabular}{llcc}
\hline No. & \multicolumn{1}{c}{ Characteristics of student } & $\mathrm{n}(=156)$ & $\%$ \\
\hline 1 & Sex & & \\
\hline & Male & 105 & 67,3 \\
& Female & 51 & 32,7 \\
\hline 2 & Allowance $(\mathrm{Rp})$ & & \\
\hline & $1.000-10.000$ & 94 & 60,3 \\
& $11.000-20.000$ & 56 & 35,9 \\
& $21.000-30.000$ & 6 & 3,8 \\
\hline
\end{tabular}

The food recall data that has been processed using the nutrition survey application are then arranged by grouping food types such as the frequency of daily food consumption equalized to food consumption per week according to the rules in the optifood application [5] as seen in Table 2. This table shows that the equalization of daily consumption becomes consumption a week is based on the percentage of subjects who eat food. Example: Eggs, if in one group of students it is found that $40 \%$ of students consume eggs, the maximum egg consumption in a week according to Table 2 . is five times.

Table 2. Maximum Food Frequency in a Week based on Percentage of Food Consumption per day

\begin{tabular}{cc}
\hline $\begin{array}{c}\text { Percentage of Subjects Consuming } \\
\text { Food }(\%)\end{array}$ & $\begin{array}{c}\text { Equalized Weekly Maximum } \\
\text { Intake Frequency (times) }\end{array}$ \\
\hline $0-5$ & 1 \\
$6-12$ & 2 \\
$13-22$ & 3 \\
$23-34$ & 4 \\
$35-47$ & 5 \\
$48-65$ & 6 \\
$66-100$ & 7 \\
\hline
\end{tabular}


The results of the optifood analysis for the portion of food consumed every week by school boys aged 10-12 years showed that on average school children consumed food in the Grains and grain products group with a frequency of 7 times a week. The types of food from the Grains and grain products group are rice and noodles. Because rice is a staple food for school children. Meanwhile, noodles are another staple food that children often consume both at home and at school as one of the snacks chosen by students. Chung, Lee, and Cho [6] in their publication stated that based on the 2001-2002 NHANES data in America, it is shown that the 9-18-year age group ranks the highest in noodle intake, that is $353.0 \mathrm{~g}$, followed by the order of 19-50 years with $333.5 \mathrm{~g}$, aged 51-70 years with $280.4 \mathrm{~g}$, older. from 71 years with $252.3 \mathrm{~g}$, and 1-8 years with $221.5 \mathrm{~g}$. Based on gender, men consume more noodles than women. Other than that, currently in overcoming the problem of stunting, consumption of various staple food sources is a good choice. So that the noodles which are also a staple food can be an option. One study showed that consumption of milk and fortified noodles was associated with a reduced chance of stunting in Indonesian children [7].

Meat, fish and eggs, beverages and Savory snacks are consumed 4 times a week. In this food group, the types of food most often consumed by school children are chicken and eggs. The type of chicken that is often consumed by school children, apart from fried chicken from the home menu, is also fast food with a menu of fried chicken options, which is a type of snack food most often consumed by children. Eggs are also a favorite food for school children, apart from being processed eggs from the home menu for school children, they also often eat snacks with egg rolls. This snack food that comes from fast food can indeed contribute calories for the nutritional needs of school children.

However, because fast food has unbalanced nutrients (high-calorie foods that contain more fat, cholesterol, salt and sugar and less vitamins, minerals and other nutrients), if consumed in excess it can cause obesity. Such as the findings in a study that looked at the effect of fast-food consumption on the health of school children (9-13 years) showed that 100 percent of school children aged 9 years were found to be obese grade 1 (mild obesity). School children aged 10 years, 11 years and 13 years respectively amounted to $42.8 \%$; 8.6\%; and $8.3 \%$ were found to be obese grade 3 (severe obesity). Among school children aged 12 years, $36.3 \%$ were obese level 2 (moderate obesity). The Savory snacks group is consumed by schoolchildren with savory foods such as chiki and chitato.

It was also found that the food group for Fruits and Vegetables was consumed only 2 times a week. This shows that this school boy rarely consumes vegetables and fruit. It can clearly be seen in Table 3 and Table 4 below.

Table 3. Servings per week of food group consumed by school boys of age 10-12 Years

\begin{tabular}{clccc}
\hline No. & Food Group & $\begin{array}{c}\text { Average } \\
\text { Servings week }\end{array}$ & $\begin{array}{c}\text { Low Servings } \\
\text { week }\end{array}$ & $\begin{array}{c}\text { High } \\
\text { Servings } \\
\text { week }\end{array}$ \\
\hline 1 & Bakery \& breakfast cereals & 2 & 0 & 4 \\
2 & Beverages (non-dairy or blended dairy) & 28 & 0 & 56 \\
3 & Composites (mixed food groups) & 13 & 0 & 26 \\
4 & Dairy products & 4.5 & 0 & 9 \\
5 & Fruits & 11 & 0 & 22 \\
6 & Grains \& grain products & 82 & 0 & 164 \\
7 & Legumes, nuts, seeds & 10 & 0 & 20 \\
8 & Meat, fish \& eggs & 29,25 & 0 & 58.5 \\
9 & Savory snacks & 28 & 0 & 56 \\
10 & Sweetened snacks \&desserts & 17.5 & 0 & 35 \\
11 & Vegetables & 6 & 0 & 12 \\
12 & Snacks & 7.5 & 0 & 15 \\
13 & Staples & 1.5 & 0 & 3 \\
\hline
\end{tabular}


Table 4. Servings per week of the sub-group of food consumed by school boys aged 1012 years

\begin{tabular}{|c|c|c|c|}
\hline Food Sub Group & Food Group & $\begin{array}{c}\text { High } \\
\text { Servings } \\
\text { week } \\
\end{array}$ & $\begin{array}{l}\text { High Servings } \\
\text { week of food } \\
\text { group } \\
\end{array}$ \\
\hline MyFoods Special Bakery & Bakery \& breakfast cereals & 4 & 4 \\
\hline $\begin{array}{l}\text { Brewed tea, herbal infusions (w/wo } \\
\text { sugar or milk) }\end{array}$ & $\begin{array}{l}\text { Beverages (non-dairy or } \\
\text { blended dairy) }\end{array}$ & $\begin{array}{c}4 \\
34\end{array}$ & $\begin{array}{l}4 \\
56\end{array}$ \\
\hline $\begin{array}{l}\text { Chocolate beverage or powder mix } \\
\text { (nondairy) }\end{array}$ & $\begin{array}{l}\text { Beverages (non-dairy or } \\
\text { blended dairy) }\end{array}$ & 19 & 56 \\
\hline $\begin{array}{l}\text { Sugar-sweetened beverages (soda, } \\
\text { processed or artificial juices) }\end{array}$ & $\begin{array}{l}\text { Beverages (non-dairy or } \\
\text { blended dairy) }\end{array}$ & 3 & 56 \\
\hline $\begin{array}{l}\text { Grain's products/fillings (sandwiches, } \\
\text { burgers, samosas, enchiladas) }\end{array}$ & $\begin{array}{l}\text { Composites (mixed food } \\
\text { groups) }\end{array}$ & 26 & 26 \\
\hline $\begin{array}{l}\text { Sweetened dairy products/desserts } \\
\text { (flan, custard, sweetened yoghurt, ice } \\
\text { cream) }\end{array}$ & $\begin{array}{l}\text { groups) } \\
\text { Dairy products }\end{array}$ & 9 & 9 \\
\hline MyFoods Special Fruits & Fruits & 10 & 22 \\
\hline Vitamin C-rich fruit & Fruits & 12 & 22 \\
\hline $\begin{array}{l}\text { Enriched/fortified grains and } \\
\text { products, whole or refined }\end{array}$ & Grains \& grain products & 16 & 164 \\
\hline MyFoods Special Grains & Grains \& grain products & 22 & 164 \\
\hline $\begin{array}{l}\text { Refined grains and products, } \\
\text { unenriched/unfortified }\end{array}$ & Grains \& grain products & 126 & 164 \\
\hline $\begin{array}{l}\text { Nuts, seeds, and unsweetened } \\
\text { products }\end{array}$ & Legumes, nuts, seeds & 20 & 20 \\
\hline Blood, bloods sausage & Meat, fish \& eggs & 6 & 58.5 \\
\hline $\begin{array}{l}\text { Eggs } \\
\text { Poultry rabhit }\end{array}$ & Meat, fish \& eggs & 17 & 58.5 \\
\hline Poultry, rabbit & Meat, fish \& eggs & 29 & 58.5 \\
\hline Processed meat & Meat, fish \& eggs & 10.5 & 58.5 \\
\hline MyFoods_Special Savory Snacks & Savory snacks & 56 & 56 \\
\hline $\begin{array}{l}\text { MyFoods_Special Sweetened Snacks } \\
\text { and Desserts }\end{array}$ & $\begin{array}{l}\text { Sweetened snacks \& } \\
\text { desserts }\end{array}$ & 35 & 35 \\
\hline Condiment vegetables & $\begin{array}{l}\text { desserts } \\
\text { Vegetables }\end{array}$ & 3 & 12 \\
\hline MyFoods_Special Vegetables & Vegetables & 9 & 12 \\
\hline
\end{tabular}

Overview of food consumption for school girls aged 10-12 years is almost the same as for school boys. These school girls also eat the Grains \& grain products group most often with a frequency of 7 times a week. The types of food most often consumed by school girls are rice and noodles. Rice is a daily staple food for school children with a menu of white rice and fried rice, and the most commonly consumed noodles are instant noodles, meatball noodles and fried noodles. These noodles are consumed by children both at home and at school as a main meal or snack.

This school girl also often consumes foods from the Meat, fish \& eggs group with a frequency of 6 times a week such as fish, eggs and meat with a menu of meat balls, beef jerky, and burgers. Apart from that, foods in the Beverages (non-dairy or blended dairy) and Savory snacks are also often consumed by school girls, which is 4 times a week such as sweet tea, chatime-based drinks, various drink menus from the Starbuck type.

The Fruits group was consumed 3 times a week, while the Vegetables group was consumed only once a week. In addition, this school girl also consumes the Sweetened snacks \& desserts 
group 3 times a week, such as bread, cake, toast, pastries and molen. The consumption of these sugary snack foods can contribute a large number of calories to the daily calorie needs of school girls. Research conducted on school children in Italy regarding the consumption of Beverages and snacks at school and away from school [8] showed that there was a significant relationship between consumption of sugary drinks, snacks, milk-based drinks compared to lowcarbohydrate drinks, fruits and vegetables. And they consume it more outside of school.

When compared with the food consumption of school boys, these girls consume less vegetables. This can clearly be seen in Tables 5 and 6 .

Table 5. Servings per week of Food Group Consumed by school girls aged 10-12 years

\begin{tabular}{llrcr}
\hline No. & Food Group & $\begin{array}{c}\text { Average } \\
\text { Servings } \\
\text { week }\end{array}$ & $\begin{array}{c}\text { Low } \\
\text { Servings } \\
\text { week }\end{array}$ & $\begin{array}{c}\text { High } \\
\text { Servings } \\
\text { week }\end{array}$ \\
\hline 1 & Bakery \& breakfast cereals & 4.3 & 0 & 8.6 \\
2 & Beverages (non-dairy or blended & 25.5 & 0 & 51 \\
& dairy) & 12 & & \\
3 & Composites (mixed food groups) & 3 & 0 & 24 \\
4 & Dairy products & 10 & 0 & 6 \\
5 & Fruits & 86 & 0 & 20 \\
6 & Grains \& grain products & 5.5 & 0 & 162 \\
7 & Legumes, nuts, seeds & 50 & 0 & 11 \\
8 & Meat, fish \& eggs & 27 & 0 & 100 \\
9 & Savory snacks & 17.7 & 0 & 54 \\
10 & Sweetened snacks \&desserts & 5 & 0 & 35.5 \\
11 & Vegetables & 3 & 0 & 6 \\
12 & Snacks & 11.5 & 0 & 23 \\
13 & Staples & 1 & 0 & 2 \\
\hline
\end{tabular}

Table 6. Servings per week of sub-group of food consumed by school girls of age 10- 12 Years

\begin{tabular}{|c|c|c|c|}
\hline Food Sub Group & Food Group & $\begin{array}{l}\text { High } \\
\text { Servings } \\
\text { week }\end{array}$ & $\begin{array}{l}\text { High Servings } \\
\text { week of food } \\
\text { group }\end{array}$ \\
\hline $\begin{array}{l}\text { Enrihched/fortified bread, whole or } \\
\text { refined grain }\end{array}$ & $\begin{array}{l}\text { Bakery \& breakfast } \\
\text { cereals }\end{array}$ & 0.4 & 8.6 \\
\hline MyFoods_Special Bakery & $\begin{array}{l}\text { Bakery \& breakfast } \\
\text { cereals }\end{array}$ & 5 & 8.6 \\
\hline $\begin{array}{l}\text { Sweetened bakery products, } \\
\text { unenriched/unfortified }\end{array}$ & $\begin{array}{l}\text { Bakery \& breakfast } \\
\text { cereals }\end{array}$ & 3.2 & 8.6 \\
\hline $\begin{array}{l}\text { Brewed tea, herbal infusions (w/wo } \\
\text { sugar or milk) }\end{array}$ & $\begin{array}{l}\text { Beverages (non-dairy } \\
\text { or blended dairy) }\end{array}$ & 38 & 51 \\
\hline \multirow[t]{2}{*}{$\begin{array}{l}\text { Chocolate beverage or powder mix } \\
\text { (nondairy) }\end{array}$} & $\begin{array}{l}\text { Beverages (non-dairy } \\
\text { or blended dairy) }\end{array}$ & 13 & 51 \\
\hline & $\begin{array}{l}\text { Composites (mixed } \\
\text { food groups) }\end{array}$ & 24 & 24 \\
\hline $\begin{array}{l}\text { Grain's products/fillings } \\
\text { (sandwiches, burgers, samosas, } \\
\text { enchilades) }\end{array}$ & $\begin{array}{l}\text { Grains \& grain } \\
\text { products }\end{array}$ & 6 & 6 \\
\hline
\end{tabular}




\begin{tabular}{llrr}
\hline $\begin{array}{l}\text { Sweetened dairy products/desserts } \\
\text { (flan,custard, sweetened yoghurt, }\end{array}$ & Fruits & 5 & 20 \\
ice cream) & Fruits & 15 & 20 \\
MyFoods_Special Fruits & Grains \& grain & 32 & 162 \\
Vitamin C-rich fruit & products & 33 & 162 \\
Enriched/fortified grains and & & 97 & 162 \\
products, whole or refined & Grains \& grain & & \\
MyFoods_Special Grains & products & 11 & 11 \\
Refined grains and products, & Grains \& grain & 7 & 100 \\
unenriched/unfortified & products & 19 & 100 \\
Nut, seeds, and unsweetened & & 6 & 100 \\
products & Legumes, nuts, seeds & 59 & 100 \\
Blood, bloods sausage & Meat, fish \& eggs & 9 & 100 \\
Eggs & Meat, fish \& eggs & 54 & 54 \\
Fish without bone & Meat, fish \& eggs & 35. \\
Poultry, rabbit & Meat, fish \& eggs & 5 & 6 \\
Processed meat & Meat, fish \& eggs & & 6 \\
MyFoods_Special Savory Snacks & Savory snacks & 1 & \\
MyFoods_Special Sweetened & Sweetened snacks \& & 5 & \\
Snacks and Desserts & desserts & & \\
Condiment vegetables & Vegetables & & \\
MyFoods_Special Vegetables & Vegetables & & \\
& &
\end{tabular}

Overview of the consumption of school children who generally eat more foods that are high in calories, fat and protein but low in fiber can cause them to be at risk for obesity. If we look at the description of the food groups consumed by school children, they are very frequent (consumption $>7$ times a week) for staple foods. Likewise for food sources of protein. They rarely (only 1-2 times a week) eat vegetables and fruit. At this school age, the intake of all nutrients must be met in accordance with the needs and in balance to achieve maximum growth and good learning achievement.

School children's diet is actually still under the responsibility of the mother as the person who manages and provides food for her family. However, if mothers can manage food for their children well, it is possible that this obesity problem can be prevented. As research conducted by Bahatheg (2021) [9] conducted in three countries namely Saudi Arabia, UK, and, Turkey found that most parents care about their children's nutritional intake and prepare meals at home (96.1\%) during the lockdown and sixty-three percent showed that children did not gain weight. This means that if parents pay attention to their children's food intake and provide food at home properly and adequately, they can prevent children from eating snacks, most of which are highcalorie foods. (Like fast food).

The high consumption of high-calorie foods in school children is partly due to the ease of ordering food, namely through an on-line food ordering application, which is currently widely offered. This application is the result of current technological developments. So that without having to leave the house the children can easily get the food they want through this application which can be downloaded via the android phone owned by this schoolchild.

The ease of ordering food through online applications today can affect a person's diet and nutritional status. This is evidenced by a study conducted by Harahap, Aritonang, and Lubis [10] which showed that there was a relationship between the frequency of ordering food online 
and obesity $(\mathrm{p}<0.001)$ and there was no relationship between the type of food and obesity $(\mathrm{p}=$ 0.099) in college students. Medan Area University.

Efforts to overcome obesity is also a WHO program. Efforts made by WHO to overcome this obesity problem are by making an "Implementation Plan to End Obesity in Children". These activities include; WHO encourages countries to implement policies to address the environment in which children grow up today, which can increase the risk of obesity. They should aim to reduce consumption of cheap, packaged, energy-dense and low-nutrient food and drink, and support healthier food and drink choices. They should promote greater physical activity through games and sports, to reduce the time children spend on sedentary screen-based activities" [11].

\section{Conclusion}

Based on the results of the study, it can be concluded that school children more often consume foods that are high in calories, fat and protein but low in fiber, namely foods from the staple food group, protein sources, and calorie and sweet drinks, as well as sweet and savory snacks. This pattern of food consumption can cause over weight and even obesity in school children which can have an impact on their health and learning achievement.

\section{Acknowledgment}

The authors would like to give the highest appreciation for the support and information given by all participants and informants involved in this research, especially for the field assisting team collecting the data from the community in Medan City, North Sumatera Province, Indonesia.

\section{References}

[1] Khomsan, Ali.: Pangan dan Gizi untuk Kesehatan. Jakarta: PT. Raja Grafindo Persada (2010).

[2] Notoatmodjo, S. Promosi kesehatan dan perilaku kesehatan. Edisi Revisi. Penerbit Rineka Cipta. (2012).

[3] Badriyah., Widari, N. S., and Gamal, A.: The Relationship of Consumption of Food and Nutritional Status with Students Achievement Academic (Case Study at the University of WR Supratman Surabaya, Indonesian). Archives of Business Research, 5(12), 191-197. (2017).

[4] USAID \& Spring: Optifood. (2013).

[5] Skau JKH, Bunthang T, Chamnan C, Wieringa FT, Dijkhuizen MA, Roos N, \& Ferguson EL.: The use of linear programming to determine whether a formulated complementary food product can ensure adequate nutrients for 6-to 11-month-old Cambodian infants. Am J Clin Nutr 2014; 99:130 8. (2014).

[6] WHO, Fanta 2: Optifood, Manual User? Jakarta: SEAMEO RECFON. (2011).

[7] Chung Chin Eun, Lee Kyung Won, and Cho Mi Sook: Noodle consumption patterns of American consumers: NHANES 2001-2002. Nutrition Research and Practice 2010 Jun; 4(3): 243-251. Published online 2010 Jun 29. doi: 10.4162/nrp.2010.4.3.243, (2010).

[8] Pfanner Regina Moench, Sun Kai, de Pee Saskia, Akhter Nasima, Badham Jane, Bloem Martin William, and Kraemer Klaus: Consumption of Micronutrient-Fortified Milk and Noodles is Associated with Lower Risk of Stunting in Preschool-Aged Children in Indonesia. Food and Nutrition Bulletin. December 2011, 32(4):347-53. DOI:10.1177/156482651103200406, (2011).

[9] Losasso Carmen, Cappa Verovica, Neuhouser Marian L., Giaccone Valerio, Igino Andrighetto, and Ricci Antonio: Students' Consumption of Beverages and Snacks at School and Away from 
School: A Case Study in The North East of Italy. Frontiers In Nutrition, 2:30. doi: 10.3389/fnut.2015.00030, (2015). 